\title{
Pak-China Boundary Agreement: Factors and Indian Reactions
}

\author{
Manzoor Khan Afridi ${ }^{1} \&$ Abdul Zahoor Khan ${ }^{2}$ \\ ${ }^{1}$ Head of Department of Politics and International Relations, Faculty of Social Sciences,International Islamic University, \\ Islamabad Pakistan. \\ ${ }^{2}$ Assistant Professor at Department of History and Pakistan Studies, Faculty of Social Sciences, International Islamic \\ University, Islamabad Pakistan. \\ Correspondence: Manzoor Khan Afridi, Head of Department of Politics and International Relations, Faculty of Social \\ Sciences, International Islamic University, Islamabad Pakistan.
}

Received: October 30, 2015

Accepted: November 16, 2015

Available online: December 16, 2015

doi:10.11114/ijsss.v4i2.1296

URL: http://dx.doi.org/10.11114/ijsss.v4i2.1296

\begin{abstract}
Aim of the paper is to discuss the Sino-Pakistan boundary agreement and to analyze the factors responsible. In 1960, Pakistan put forward its offer to China for border demarcation. The Chinese Government did not respond to the Pakistani offer. China was working hard to persuade India for the border settlement. But when the hopes for the Sino-Indian rapprochement failed, China asserted for negotiations with Pakistan. China was also motivated by the concept that the Western powers might manipulate the situation between the two countries and could assert pressure on Pakistan's decision making process which would bring hostilities between the two countries. If China would more delay its border negotiations with Pakistan, the US wishes might come true and a permanent stalemate in relations could persist in future. As long as Pakistan was dependent on the US for its military and economic needs, it seemed difficult to get closer with China and negotiate for a border demarcation. Despite the opposition of India and the US, both Pakistan and China demarcated their border and signed a boundary agreement.
\end{abstract}

Keywords: Pakistan, China, Boundary, Kashmir, Xinjiang, India

\section{Introduction}

In the start of the decade (1960s), both countries signed various bilateral agreements which transformed their relationship into an entente cordiale. Pakistan struggled to maintain a balanced relationship between the United States and China, but emphasized more cordial engagement with the socialist states. Pakistan and China signed their boundary, air and trade agreements. Pakistan took back step to its previous position of pre-alliance by supporting the Communist China's seat in the United Nations Organization and One China policy. On its part, China too supported openly Pakistan's views on Kashmir issue, emphasized on the solution of the problem according to the United Nations resolutions and wishes of the Kashmiri people. To remind, since its inception, China had been taking a somewhat neutral stance on Kashmir. Also, the PRC overtly backed Pakistan during the latter's war with India in 1965.

Also during this period, China repeatedly assured Pakistan of all its possible help for the latter's independence, sovereignty and territorial integrity. Here along with the US and USSR, the Indian factor was dominant to shape the two countries' policies toward each other. Their common enmity with India led them to foster their ties particularly in defense sector. The China continued support to Pakistan to contain the Indian influence in the South Asia (Bhutto, 1965) and maintained there a balance of power between Islamabad and New Delhi and also between Beijing, Moscow and Washington.

The first test in this period was the Indo-Pakistan war of 1965, in which, China wholly supported Pakistan. During the 1965 conflict, Pakistan faced grim situation. Despite an ally, the United States first suspended arms supplies to Pakistan by imposing embargo and later in a statement by the State Department issued a policy guideline declaring its neutrality in the conflict. Pakistan requested the US to use its influence to stop the war, but the latter rejected the request. In the time of need, China intervened in the favor of Pakistan. On 16 September 1965, China demanded India by giving an ultimatum to the Indian Embassy in Beijing for the dismantling of Indian military activities and kidnapped Chinese border inhabitants, within three days, with the Chinese Sikkim border. The PRC also warned that in the failure of its demands, India would face full responsibility of all serious consequences on its part (International Organization, 1966).

Between 1964 and 1966, several high-ranking personalities of both countries visited each other. Chinese Premier Zhou 
En-lai paid an official visit to Pakistan in February 1964 which was reciprocated by Pakistani President Ayub Khan in March 1965, to "coincide with the second anniversary of the Sino-Pakistan border agreement". He and his delegates received a most-cordial welcome in Beijing in the history of China's reception for an Asian head of state. "China offered a $\$ 60$ million interest-free loan to Pakistan to import heavy machinery and during his visit to China, Ayub publicly expressed appreciation of this gesture which involved special sacrifices on the part of China to promote self-reliance in a fellow Asian country". The following year, President Liu Shaoqi paid a visit to Pakistan and was given him an exceptional warm reception (Bhatty, 2003).

The paper also looks into the superpower policies and interactions which affected the Sino-Pakistan relations in a constructive way. The Pakistan's estrangement from America, by ignoring its allied status, giving credits to a nonaligned India and the Soviet blessings for India gave a new structure to Sino-Pakistan relations based on common interests. The US and the Soviet antagonism with Communist China, the latter's test of nuclear device in 1964, and Pakistan's friendly gestures to China, created an opportunity for India to look forward the superpowers' help against Pakistan and China. India became 'bone of contention' between Pakistan's relations with the United States and the Soviet Union. India's seeking easy-going relationships with superpowers also added a dilemma in Chinese already hostile environment with the two superpowers.

India wanted to build a common Indo-US front against China, when the New Delhi requested Washington about aid in 1963, for the "advanced supersonic aircraft" to match herself with "Pakistan's American F-104s and Chinese MIG-21s". On the other hand, many Indians believed that "Russia, a major country in Asia, sharing a frontier extending over thousands of controversial miles with China" was "a surer deterrent to Chinese venture" (Wriggins, 1970). Consequently, the security-torn climate of the region gave rise to a kind of "balance of power", forming two alignments, the Indo-Soviet and the Sino-Pakistan united fronts, while the United States was in-between, changing her position. Z.A. Bhutto has explained the situation as a result of the Indo-Soviet and the Sino-Pakistan relations in these words: "If India can talk to the 200 million people of the Soviet Union, we can talk to the 650 million people of the People's Republic of China on the same basis" (Bhutto, 1964).

\section{Sino-Pakistan Boundary Agreement}

The most important event in so far Sino-Pakistan relations was the demarcation of their common border which was the take off point for their later entente. In the late of 1950s, Sino-Pakistan relations were touching their nadir. It was reported that the Chinese troops had entered into Pakistani territory of Hunza and had taken away some cattle from there (Khan, 1967). As was already facing the security vulnerability from Indian and Afghanistan sides, Pakistan was disturbed over these violations of its border. Pakistan's Foreign Minister, Manzur Qadir, mentioned in a news conference in Karachi on 21 October 1959 that Pakistan would defend its frontiers with possible means (Asian Recorder, 1959). President Ayub Khan declared that his government would approach China for boundary negotiations. In December 1959, in a cabinet meeting, the consensus was that the Chinese were unlikely to respond to any suggestion for the demarcation of the border but Ayub Khan insisted that there was no harm in preparing a memorandum in this regard and getting in touch with the Chinese (Khan, 1967). Ayub Khan ordered the Gilgit Scouts to move along the Sino-Pakistan border and sealed the border with Xinjiang (Khan, 1961).

With the Pakistan's somewhat new balanced and independent foreign policy, the Sino-Pakistan border remained peaceful throughout 1960 and 1961. On 27 May 1962, a high level conference was held in Pakistan under the chairmanship of President Ayub Khan, in which an indication was given for reappraisal of Pakistan's foreign policy. There was a consensus in the conference that in the wake of Western assistance to India, Pakistan should pursue its foreign policy in such a manner that it get closer to China on one hand and also keep normal relationship with the US on another hand (Pakistan Horizon, 1965). Pakistan obviously abandoned its total dependence on the US. A clear gesture for such a policy was the appointment of Muhammad Ali Bogra as Minister of Foreign Affairs, which had good credentials in the United States and personal friendship with Zhou En-lai. Manzur Qadir disclosed on 15 January 1961 that China had agreed in to demarcate its boundary with Pakistan and talks in this regard were in process. A troublesome situation created after the Ayub Khan's visit to US in July 1961 when the Chinese Ambassador in Pakistan, Ding Guoyu asked Ayub Khan for support of Communist China's admission in the UN. Ayub Khan made such a support conditional to China's willingness to Pakistan's offer of demarcation of their border (Khan, 1967). After so many meetings between the Chinese Ambassador and Pakistan's leaders in Karachi, the two countries made a way for the final settlement of the border. Pakistan agreed then to support PRC for membership in the UN and PRC also was willing then for negotiations on border. The Chinese Government withdrew its issued disputed maps in January 1962. The Chinese Government officially responded to Pakistan on 27 February 1962. In both Beijing and Karachi, on 3 May, 1962, a statement issued of the provisional agreement to demarcate boundary (Dawn, 1962).

Sino-Pakistan negotiations officially began on 13 October, 1962. After a long process of diplomatic channel, China and 
Pakistan became able to settle their border issue. Consequently, both the countries Foreign Ministers, Zulfiqar Ali Bhutto and Chen Yi, respectively signed their boundary agreement on 3 March, 1963 in the Great Hall of the People in Beijing, in the presence of the Chairman of the People's Republic of China and Premier Zhou En-lai (The American Journal of International Law, 1963). Both the Governments released new maps concerning the agreed frontier. The boundary was the result of some give and take policy. China ceded over hundreds of miles territory to Pakistan and on the return; Pakistan recognized the Chinese sovereignty over hundreds of square kilometers of land in Northern Kashmir and Ladakh. The agreement was a win-win situation for both countries. Pakistan got a large area and China too consolidated her position in Ladakh, an area to which President Ayub had referred before the agreement that Pakistan would not recognize any arrangement between China and India, as the area was a disputed territory between India and Pakistan (Bhutto, 1976). By giving the Ladakh area under the Chinese authority, Pakistan withdrew from its previous claim and gave an upper hand to China over India.

Upon the conclusion of agreement, Pakistan's leaders were happy to say that "we were the gainers by entering into negotiations to delimit our boundary with China. We saw no reason to delay the conclusion of an agreement about it, for we ourselves had initiated the negotiations. We came to a speedy and satisfactory settlement of the boundary. Under this settlement, Pakistan gained about 750 square miles of territory, some of it rich in natural resources, particularly the salt mines of Oprang, which the people of Hunza and surrounding territory consider necessary for their needs and for their economic well being. It is a matter of the greatest importance that through this agreement we have removed any possibility of friction on our only common border with the People's Republic of China. We have eliminated what might well have become a source of misunderstanding and of future troubles" (Bhutto, 1964). The boundary agreement eliminated the myth of Chinese threat which the US-led Western countries had projected for a long time. It proved that China was a peaceful neighbor with no intention to climb on Pakistan. The need for demarcation of boundary forced by the following factors.

1. China had an experience of war with India related to their boundary and Pakistan had tough time with India as well. By finding a common enemy, the two states could work together better and cooperate against India. According to Bhutto "An attack by India on Pakistan would no longer confine the stakes to the independence and territorial integrity of Pakistan. An attack by India on Pakistan would also involve the security and territorial integrity of the largest state in Asia" (Ibid. p, 82). Apparently he meant, the P.R. China. Thus it was advantageous for both countries to solve their border peacefully.

2. Pakistan felt that likely, the differences which were already existed with China due to the Pakistan's pro-West position could flare up on the boundary. The agreement reiterated that the purpose of this agreement was to ensure tranquility along the border, in order to develop friendly communication between the two countries. The fast changing security scenario of the region was posing a danger that an undemarcated border could have caused conflict as was in the Sino-Indian border problem (Hailin, 2008).

3. Pakistan had been engaged with India primarily of the Kashmir question which was resulted into war and hostilities. By going closer to China for the boundary issue, Pakistan was trying to get concessions from India on Kashmir, by using the China card. It was evident from the Indian protests regarding the Sino-Pakistan boundary negotiations. Pakistan was of the hope that China could support her position on Kashmir issue, that latter proved. "The veteran Kashmir leader, Ghulam Abbas, proclaimed China the only dependable friend and ally of Pakistan, and one whose friendship could be of great value in liberating Kashmir from Indian occupation (Dobell, 1964).

4. It was also Pakistan's effort to persuade the United States to pressure India for the solution of the Kashmir problem. It was a signal for the US that if she had failed, Pakistan had another option for the problem's solution that was China.

5. China had already resolved her boundary issues peacefully with its neighbors, like Burma and Nepal. China was interested to present itself as a peace-loving country by resolving the same issue with Pakistan. Pakistan too was looking seriously the Chinese developments with its neighbors and was concluded that a peaceful solution of the boundary was likely to take place.

6. Over the United States' giving assistance to India in the Sino-Indian border war of 1962, Pakistan was understandably unhappy over these overtures. Although the US had declared that the aid was primarily for the purpose to contain China, but Pakistan seemed it a more powerful India threatening its sovereignty. Bhutto expressed its anxiety that the weapons given to India by the US would be used against Pakistan as India had already solved five of its disputes by the use of force. In 1963, the Indian President once said in the US: "India will be able to settle the problem only by having strength with which to back her bargaining power" (Ibid. p. 8).

7. In November 1962, with the help of United States and United Kingdom, Pakistan and India agreed to resume their talks. "The idea was to induce Pakistan gradually to turn in the opposite direction by insisting on Indo-Pakistan co-operation instead of a rupture of Pakistan's relations with China" (Bhutto, 1965). Realizing the situation back of the 
1959 proposal of India and Pakistan for a joint defense of the subcontinent, China worried of these talks which might bring the same dilemma for it. When the talks reached to a stalemate, Pakistan also realized that it was merely Western attempt to make a room for sympathy in Pakistan and tone down the latter's criticism of the Western aid to India. It was beneficial for China to engage itself with Pakistan for border talks to neutralize the joint Indo-Pakistan development and minimize the outside powers' influence in the region.

8. As Pakistan readjusted its policy of balance between the West and the Communist blocs, in 1961, Pakistan was agreed to get the Soviet assistance in the shape of agreement for exploration of its oil resources. China was worried about this Soviet's offer. Later, the victory of China over India in its war proved for Pakistan that China was better option than the Soviet Union to approach for sustained warm relations.

9. The boundary agreement gave recognition to Pakistan's control over Azad Kashmir from a regional power against the Indian charges. It was also mentioned in the agreement that the final boundary would be redrawing in future when the Kashmir dispute solved. It means that Pakistan was successful to denounce the Indian claim over Kashmir and projected it as a disputed territory between itself and India, as Pakistan was demanding the disputed position of Kashmir in the United Nations, illegally occupied by India. On May 31, 1962China told to the Indian Embassy in Beijing by Note that it had never recognized the Indian claim over Kashmir as her sovereign territory without reservation (Ambekar and Divekar, 1964).

10. The Xinjiang problem has always been a trouble for Beijing Regime and fostered by the Soviets since the early 1960s. The Sino-Pakistan boundary touches Xinjiang with the Northern Areas of Pakistan. It was in interest of Beijing to conclude a boundary agreement with Pakistan as early as possible for the stability of its area, as a Muslim Pakistan has had a natural religious and cultural bond with the people of Xinjiang.

It should be noted that Pakistan signed a civil aviation agreement with China in August 1963. Under this agreement, Pakistani planes were allowed to land in Canton and Shanghai and Pakistan gave permission to Chinese jets for use of the Dacca airport. The United States Government was not happy over this development. The US State Department expressed that this agreement was "an unfortunate breach of the free world solidarity and postponed, subsequently, the granting of a loan of $\$ 4.3$ million for further improvements of the Dacca airport" (Lerski, 1968). An interesting fact is that, the United States never challenged the Indian bilateralism with the US and USSR (Ibid.).

\section{Indian Reactions}

India was perhaps the only country where the agreement was highly criticized. India was not willing to recognize the Sino-Pakistan Boundary Agreement as a legitimate decision. She had never accepted Pakistan's sovereignty over its northern areas and Azad Kashmir. It was long before the conclusion of the agreement that India sharply agitated over it. As the agreement stated that it was between "China's Sinkiang and the contiguous areas the defence of which is under the actual control of Pakistan" (Pakistan's Northern Areas and Azad Kashmir), India reacted promptly. "Delhi protested at this de facto recognition of Pakistan control of Hunza and Baltistan, and China rejected the Indian protest" (Dobell, 1964).

While speaking on the Sino-Pakistan Boundary Agreement, Indian Prime Minster Nehru remarked that China and Pakistan were going to demarcate the border "of the illegally occupied area of Kashmir with Sinkiang". It was Indian position that was not accepting the boundary agreement on the ground that Pakistan had no legitimacy of her contiguous areas with Chinese Sinkiang. He further said that "Sardar Swaran Singh, Leader of the Indian Delegation, immediately made our (Indian) position clear to President Ayub Khan and Mr. Bhutto in Rawalpindi, and again to Mr. Bhutto, later, when the talks were resumed in Delhi, in January last". India was protesting consistently. Again he reminded: "On January 26, we lodged a protest with the Government of Pakistan against the decision announced in the joint communique issued by them (China and Pakistan) on December, 28, 1962. Another protest is being lodged with the Government of Pakistan against the signing of this Sino-Pakistan border alignment agreement in Peking". India claimed that Pakistan had surrendered a large area of India to China. "It has been stated in Karachi that the difference between the Chinese claim line and the Pakistan claim line was 3,400 squire(wrong spellings) miles. In the final agreement, Pakistan claims to have received 1,350 square miles, including 700 square miles of area which was in China's possession. The Chinese have been given 2,050 square miles under the agreement".

Delhi accused that some part of Sinkiang territory was the area of Kashmir. "According to the Survey of Pakistan maps, even those published in 1962, about 11,000 square miles of Sinkiang territory formed part of Kashmir. If one goes by these maps, Pakistan has obviously surrendered over 13,000 square miles of territory". Actually, India's accusations were less convincing in a sense of geographical realities, historical evidence and the legal arguments that the areas north of the Karakoram Range had never been under the actual administrative control of India in modern times.

Nehru criticized the boundary agreement that the delimitation of the border as stated was "on the basis of the traditional customary boundary line, including natural resources" was not so. He continued his speech in the parliament by labeling 
blame that China was involved in Indo-Pakistan differences by interference and was deteriorating the Indo-Pakistan relations for its own expansionism. India again lodged a protest note with China on 10 May 1962. He blamed in these words: "The other party to the agreement, namely China, in spite of its professions that it has never involved itself in the dispute over Kashmir or its absurd claim that the boundary negotiations have promoted friendship between the Chinese and Pakistani peoples and are in the interests of Asia and world peace is directly interfering in Indo-Pakistan relations. By doing this, China is seeking to exploit differences between India and Pakistan on the Kashmir question to further its own expansionist policy. The Government of India has made their position clear in a protest against this agreement which has been lodged with the Government of the People's Republic of China" (Ambekar and Divekar, 1964).

In another note the Ministry of External Affairs of India warned the Government of Pakistan of the grave consequences of their action and that any agreement with the Government of China, provisional or otherwise, was not to be acceptable to India (Ibid.). Both Governments of China and Pakistan replied to the Indian allegations regarding the Sino-Pakistan Boundary Agreement that the agreement was legal. China pointed out that India was not willing to demarcate its border with China and further make complications in Sino-Pakistan boundary settlement. China stated that if Nepal and Burma could delimit their borders with China, why India could not?

\section{Conclusion}

Pakistan and China demarcated their border successfully. The Government of Pakistan also made it clear to India that aim of the border demarcation with China was only to eliminate the future complexities and frictions, and the agreement was provisional in its nature. Pakistan extended its reply by stating that the agreement was in no way prejudicial to the peaceful solution of the Kashmir conflict between Pakistan and India and Pakistan's permanent representative in the UN, Sir Zafrullah Khan referred the Article 6 of the Agreement (Dobell, 1964) that when the Kashmir problem solved, the boundary negotiations would be re-open between the PRC and the legitimate authority of Kashmir and a final agreement would be sign then. It was just Indian anxiety over the improvement of Sino-Pakistan relations and the boundary's protests were only excuse. More importantly, although India had accused Pakistan of illegal occupation of the Azad Kashmir, in reality, India had never seriously challenged the Pakistan's authority of its Azad Kashmir.

\section{References}

Ambekar, G. V., \& Divekar, V. D. (1964). Sino-Pakistan “Agreement” March 2, 1963: Some Facts, Delhi.

Asian Recorder. (1959, November 21-27), 5(47), 3011-3019

Bhatty, M. A. (2003). China and South Asia. ISSI Pakistan Strategic Studies Journal, XXIII(1), 8.

Bhutto, Z. A. (1964). Foreign Policy of Pakistan: A Compendium of speeches made in the National Assembly of Pakistan, 1962-64. Karachi: Pakistan Institute of International Affairs.

Bhutto, Z. A. (1965). Pakistan and Alliances. Lahore: Agha Amir Hussain Classic.

Bhutto. Z. A. (1976). Bilateralism: New Directions. Islamabad: Ministry of Information and Broadcasting, Government of Pakistan.

Dobell, W. M. (1964). Ramifications of the China-Pakistan Border Treaty. Pacific Affairs, 37(3), 283-295.

Hailin, Y. (2008).Interview. Beijing: Expert on Sino-Pakistan relations at Asia-Pacific Center, Chinese Academy of Social Sciences, Beijing

Khan, H. R. (1961). Pakistan's Relations with the People's Republic of China. Pakistan Horizon, 14(3), 230-238.

Khan, M. A. (1967). Friends Not Masters: A Political Autobiography. London: OxfordUniversity Press

Lerski, G.J. (1968). The Pakistan-American Alliance: A Reevaluation of the Past Decade. Asian Survey, 8(5), 400-415.

Pakistan Horizon. (1965). Karachi: Speech of Pakistan's Minister for Foreign Affairs to the nineteenth session of the United Nations General Assembly held on 25 January 1965, XVIII(4), 73.

The American Journal of International Law (1963). People's Republic of China-Pakistan. Agreement on the boundary between China's Sinkiang and the Contiguous Areas. Peking, March 2, 1963. The American Journal of International Law, 57(3), 713-716.

The India-Pakistan Question. (1966). International Organization, 20(4), 788-797.

Wriggins, W. H. (1970). The Presence in Southern Asia of outside Powers. Annals of the American Academy of Political and Social Science, A New American Posture toward Asia, 48-62.

\section{$(\mathrm{cc}) \mathrm{Br}$}

This work is licensed under a Creative Commons Attribution 3.0 License 